\title{
Kesan Penyimpanan Sampel Air Liur Terhadap Kualiti DNA Genom
}

\author{
(Storage Effect of Saliva Sample on Quality of Genomic DNA)
}

\author{
ROHAYA MEGAT ABDUl WAHAB, FARAH AMIRAH MOHD NASRI, INTAN ZARINA ZAINOL ABIDIN, \\ ZAIDAH ZAINAL ARIFFIN, MUHAMMAD DAIN YAZID \\ \& SHAHRUL HISHAM ZAINAL ARIFFIN*
}

\begin{abstract}
ABSTRAK
Air liur berpotensi menjadi punca DNA yang mudah diambil bagi kajian klinikal kerana tidak invasif berbanding sampel darah. Kajian ini dijalankan untuk memencilkan dan menulenkan DNA genom daripada sampel air liur manusia serta mengkaji kesan penyimpanan terhadap kualiti DNA genom. Sampel air liur $(\mathrm{n}=5)$ disimpan dalam penimbal Tris-NaCl EDTA (TNE) pada suhu bilik $\left(25^{\circ} \mathrm{C}\right)$ mengikut tempoh masa yang ditetapkan iaitu, segar (tanpa penyimpanan), 1, 2, 3 dan 4 bulan. Pemencilan dan penulenan DNA dilakukan menggunakan kaedah fenol-kloroform. Seterusnya, PCR telah dijalankan untuk mengetahui ketulenan DNA yang diekstrak menggunakan amplifikasi pada kawasan jujukan beta-globin dan mengenal pasti kehadiran bakteria melalui jujukan yang mengekod $16 S$ rDNA. Keputusan menunjukkan fragmen DNA gen beta-globin manusia hanya berjaya diamplifikasi daripada sampel segar. Sampel air liur yang disimpan dalam penimbal TNE pada suhu bilik tidak mampu menstabilkan DNA genom manusia untuk jangka masa lama dan hanya berkesan untuk tempoh yang singkat iaitu, kurang daripada 1 bulan. Kesimpulannya, hanya sampel air liur segar sahaja yang berupaya memencil DNA genom.
\end{abstract}

Kata kunci: Ketulenan DNA; PCR; penimbal TNE; suhu bilik

\section{ABSTRACT}

Saliva is a potential source of DNA easily obtained for clinical studies because it is non-invasive compared to blood samples. This study was carried out to isolate and purify genomic DNA from human saliva sample and to study storage effect on the quality of genomic DNA. Saliva samples $(\mathrm{n}=5)$ were kept in Tris-NaCl EDTA (TNE) buffer at room temperature $\left(25^{\circ} \mathrm{C}\right)$ according to fixed time period which are; fresh (without storage), 1, 2, 3 and 4 months. Isolation and purification of DNA was carried out using phenol-chloroform method. Next, PCR was conducted to determine the purity of extracted DNA by using amplification of beta-globin sequence region and identify bacterial existence using the sequence that codes for $16 S$ rDNA. Only human beta-globin genomic DNA fragment was successfully amplified from fresh sample. Saliva sample kept in TNE buffer at room temperature was not able to stabilize human genomic DNA at long term and worked for short term storage which was less than a month. In conclusion, fresh saliva sample is needed to isolate genomic DNA.

Keywords: DNA purity; PCR; room temperature; TNE buffer

\section{PENDAHULUAN}

Air liur adalah sumber DNA yang berpotensi untuk digunakan dalam mengkaji genetik manusia. Kemajuan dalam penggunaan air liur sebagai cecair diagnostik adalah hasil daripada kepesatan kemajuan teknologi semasa. Kesannya, kemajuan teknologi semasa telah membawa kepada penggunaan air liur sebagai sumber diagnostik alternatif untuk menilai kesihatan oral malah mampu menilai kesihatan secara keseluruhan (Wong 2006). Air liur telah menjadi sumber diagnostik yang penting bagi mengkaji penyakit disebabkan oleh komposisi, fungsi dan interaksi air liur dengan sistem organ yang lain (Lima et al. 2010).

Madalli et al. (2013) mendapati air liur berpotensi untuk berfungsi sebagai bahan diagnostik yang memberikan banyak kelebihan berbanding serum. Air liur didapati mampu memberi maklumat terhadap ciri fisiologi dalaman yang normal mahupun keadaan penyakit seseorang (Javaid et al. 2015). Ini kerana perubahan terhadap ciri fisiologi seseorang akibat daripada penyakit yang dihidapinya akan menyebabkan perubahan terhadap cecair plasma yang terdapat di dalam air liur, menjadikan air liur sebagai bahan spesimen yang berpotensi untuk mendiagnosis penyakit (Lima et al. 2010). Pada masa kini, air liur telah digunakan dalam menganalisis beberapa penyakit seperti penyakit sistemik, autoimun, keturunan, kanser, kandungan paras hormon, paras dadah, pembuktian forensik dan juga penyakit oral (Javaid et al.2015; Malathi et al.2014; Mohd Faiz et al. 2012; Rathnayake et al. 2013).

Air liur didapati mengandungi pelbagai bahan biologi seperti enzim, hormon, antibakteria, antibodi, glikoprotein, elektrolit, mukosa dan bahan biologi lain (Chiappin et al . 2007; Daniel et al. 2006; Luke et al. 2015; Spielmann \& Wong 2011) yang berguna dalam melakukan diagnosis 
penyakit. Spielmann dan Wong (2011) berpendapat air liur berupaya memberikan gambaran terhadap keadaan fisiologi yang berlaku dalam sistem badan manusia termasuk melibatkan emosi, nutrisi dan variasi metabolik yang membolehkannya menjadi sumber terbaik untuk memantau kesihatan sistemik manusia. Shahrul Hisham et al. (2010) pula menggunakan air liur untuk menentukan profil penanda biologi bagi enzim laktat dehidrogenas (LDH), asid fosfatase rintang tartarat (TRAP) dan alkali fosfatase (ALP) dalam mengkaji individu yang menjalani rawatan ortodontik.

Pengumpulan sampel air liur didapati lebih berkesan, tidak invasif dan lebih mudah berbanding pengambilan sampel darah yang bersifat invasif, menyakitkan serta memerlukan tenaga pakar yang mahir (Chiappin et al. 2007; Daniel et al. 2004; Streckfus et al. 2002; Wong 2008). Kajian oleh Thomas et al. (2007) mendapati DNA yang diekstrak daripada sampel darah mempunyai kualiti yang lebih tulen untuk menjalani analisis molekul seperti PCR berbanding sampel sel pipi. Terdapat beberapa kajian terhadap sampel darah manusia dan mencit telah digunakan melibatkan pengekstrakan genom DNA dan seterusnya menjalani analisis molekul menggunakan pendekatan PCR (Hebels et al. 2013; Shahrul Hisham et al. 2010; Ruzanna et al. 2011). Walau bagaimanapun, air liur juga boleh digunakan sebagai sumber alternatif untuk mengkaji fisiologi manusia dan perkembangan rawatan terhadap penyakit sistemik (Lima et al. 2010; Mohd Faiz et al. 2012; Rohaya et al. 2010; Streckfus et al. 2000; Wong 2006; Zulham et al. 2013).

Sampel air liur juga berpotensi untuk digunakan melibatkan sampel yang sukar untuk diambil seperti sampel daripada kanak-kanak, orang kurang upaya atau pesakit yang trauma kerana tidak melibatkan penggunaan jarum (Tina Pfaffe et al. 2011). Oleh itu, air liur boleh dijadikan sebagai sumber alternatif kepada sampel darah yang bersifat invasif bagi memencilkan DNA genom untuk kajian molekul yang seterusnya. Pada masa kini didapati tiada lagi kajian melibatkan simpanan sampel air liur bagi mengkaji ketulenan DNA yang dipencilkan. Kajian ini dilakukan bagi mengenal pasti kualiti dan ketulenan DNA dari sampel air liur manusia dengan tempoh masa penyimpanan yang berbeza dengan menggunakan penimbal Tris-NaCl EDTA (TNE). Kajian ini berpotensi bertindak sebagai rujukan terhadap kajian molekul DNA klinikal melibatkan sampel air liur pada masa hadapan.

\section{BAHAN DAN KAEDAH}

\section{PENSAMPELAN}

Subjek terdiri daripada 5 individu dewasa berumur 22-25 tahun ( 3 perempuan dan 2 lelaki) telah dipilih mengikut kriteria yang telah ditetapkan seperti dalam Jadual 1. Setiap subjek kajian telah menderma sebanyak $50 \mathrm{~mL}$ air liur yang dikumpul dalam bekas steril dalam tempoh masa 2-4 jam pada hari yang sama. Subjek kajian diminta agar tidak makan atau minum dalam masa 1 jam sebelum pengumpulan sampel air liur dilakukan. Selain itu, subjek kajian perlu berkumur dengan air steril terlebih dahulu sebelum prosedur pengumpulan air liur dilakukan bagi mengelakkan sebarang kontaminasi luar. Seterusnya, air liur yang dikumpul divorteks dan dibahagikan kepada 5 tiub emparan $15 \mathrm{~mL}$ yang mewakili sampel segar, sampel selepas penyimpanan pada suhu bilik $\left(25^{\circ} \mathrm{C}\right)$ selama 1,2 , 3 dan 4 bulan.

Sebanyak $5 \mathrm{~mL}$ sampel air liur dibahagikan ke dalam setiap tiub emparan bersama dengan $3 \mathrm{~mL}$ penimbal TNE (50 mM Tris-HCl; pH 8.0, 100 mM NaCl, $0.1 \mathrm{mM}$ EDTA). Penambahan penimbal TNE adalah bertujuan untuk mengelakkan berlakunya degradasi DNA (Smith 2005). Pemencilan DNA pada sampel segar dilakukan selepas penimbal TNE ditambah, manakala sampel lain disimpan dalam penimbal TNE untuk jangka masa 0-4 bulan pada suhu bilik $\left(25^{\circ} \mathrm{C}\right)$ sebelum proses pemencilan DNA dilakukan.

JADUAL 1. Kriteria pemilihan individu sebagai subjek kajian klinikal

\begin{tabular}{cl}
\hline Bil. & Kriteria yang dikehendaki \\
\hline 1. & Bebas daripada sebarang penyakit sistemik \\
2. & Tidak mengambil ubat-ubatan atau vitamin \\
3. & Tidak mengandung \\
4. & Tidak merokok \\
5. & Mempunyai kesihatan oral yang baik \\
& mengikut indeks Plaque (PI) \\
\hline
\end{tabular}

\section{PEMENCILAN DNA}

Pemencilan DNA genom pada semua sampel dijalankan pada jangka masa yang telah ditetapkan; segar, 1, 2, 3 dan 4 bulan. Sebanyak $5 \mathrm{~mL}$ sampel air liur yang telah disimpan bersama penimbal TNE diempar pada kelajuan $3000 \mathrm{~g}$ selama 10 min pada suhu bilik. Supernatan yang terhasil dibuang dan pelet diambil untuk kegunaan seterusnya.

Pelet yang diperoleh dilarutkan ke dalam $650 \mu \mathrm{L}$ penimbal lisis (100 mM Tris- $\mathrm{HCl}$ (pH8.0), $5 \mathrm{mM}$ EDTA (pH8.0), 1\% (i/i) SDS) dan $10 \mu \mathrm{L}$ RNase (700 unit/mg) ditambah untuk mencerna RNA. Selepas pengeraman pada $37^{\circ} \mathrm{C}$ selama 1 jam, $20 \mu \mathrm{L}$ Proteinase K (200 unit/ $\left.\mu \mathrm{L}\right)$ ditambah dan campuran kemudiannya dieram semalaman dalam rendaman air pada $55^{\circ} \mathrm{C}$. Selepas pengeraman, 1 $\mathrm{mL}$ fenol-kloroform-isoamil alkohol tertepu-TE (25:24:1) ditambah pada sampel dan diempar pada kelajuan 13,000 g, pada suhu bilik selama $10 \mathrm{~min}$. Setelah dicuci, 100\% (i/i) etanol ditambah sebanyak $1 \mathrm{~mL}$ dan campuran digoncang secara perlahan sehingga mendakan terbentuk. Supernatan terhasil dibuang dan pelet dikeringkan. Setelah kering, pelet dilarutkan dalam $50 \mu \mathrm{L}$ air suling steril dan disimpan pada suhu $-20^{\circ} \mathrm{C}$.

\section{KUANTITI DAN KUALITI DNA}

Purata kepekatan (Kuantiti) DNA (ng/ $\mu \mathrm{L})$ dapat ditentukan daripada nilai bacaan spektrofotometri iaitu pada bacaan 
penyerapan jarak gelombang $260 \mathrm{~nm}$. Kualiti DNA pula ditentukan melalui nisbah bacaan dalam lingkungan 1.82.0 pada 260 dan $280 \mathrm{~nm}\left(\mathrm{~A}_{260 / 280}\right)$ yang menunjukkan anggaran DNA tulen, manakala nisbah bacaan $\left(\mathrm{A}_{260 / 230}\right)$ 2.02.2 pula menunjukkan sampel DNA adalah bebas daripada kontaminasi polisakarida (Pham et al. 2015; Steven et al. 2007). Kualiti DNA genom seterusnya dinilai melalui elektroforesis $1 \%$ (i/i) gel agarosa dan diikuti dengan visualisasi di bawah cahaya UV setelah pewarnaan etidium bromida (EtBr) dilakukan.

\section{KAEDAH TRANSKRIPTASE BERBALIK-TINDAK BALAS RANTAIAN POLIMERASE (RT-PCR)}

Kaedah RT-PCR dijalankan dengan menggunakan $25 \mu \mathrm{L}$ campuran tindak balas PCR yang mengandungi $10 \mathrm{ng}$ templat DNA, $200 \mu \mathrm{M}$ bagi setiap dNTP, $1 \mu \mathrm{M}$ bagi setiap pencetus, $2.5 \mathrm{mM} \mathrm{MgCl}{ }_{2}, 5 \mu \mathrm{L} 5 \mathrm{X}$ penimbal PCR GoTaq dan juga $5 \mathrm{U} / \mu \mathrm{L}$ Taq polimerase DNA. Bagi mengetahui kualiti DNA yang telah dipencilkan, kaedah RT-PCR dijalankan dengan menggunakan pencetus beta-globin manusia yang direka dengan menggunakan perisian Primer Premier 6.0 (Jadual 2). Manakala pencetus universal bagi $16 \mathrm{~S}$ rDNA bakteria yang digunakan merujuk pada kajian $\mathrm{Gu}$ et al. (2009) (Jadual 2). Suhu penyepuhan dan kepekatan $\mathrm{MgCl}_{2}$ bagi proses RT-PCR telah dioptimumkan. Proses RT-PCR yang sama (melibatkan kedua-dua jenis pencetus) dijalankan seperti dalam Jadual 3.

\section{HASIL PENYELIDIKAN}

\section{PEMENCILAN DNA}

Hasil pemencilan DNA bagi majoriti sampel segar, selepas penyimpanan 1, 2 dan 4 bulan menunjukkan bacaan $\mathrm{A}_{260 / 280}$ antara 1.8-2.0. Hanya sampel 3 bulan menunjukkan bacaan $\mathrm{A}_{260 / 280}$ melebihi 2.0. Hasil yang diperoleh menunjukkan sampel segar mempunyai DNA yang lebih tulen, manakala sampel yang disimpan pada tempoh satu bulan dan lebih menunjukkan terdapat pelumusan polisakarida dan protein (Jadual 4).

\section{AMPLIFIKASI FRAGMEN JUJUKAN DNA BETA-GLOBIN MANUSIA DAN 16S rDNA BAKTERIA}

Berdasarkan Rajah 1(a), fragmen bersaiz 280 pb didapati hadir pada kelima-lima lajur (L1-L5) dan menunjukkan gen beta-globin manusia bersaiz $\sim 280$ pb berjaya

JADUAL 2. Jujukan pencetus kehadapan dan pencetus berbalik bagi fragmen beta- globin dan gen kawasan pengkodan 16S rDNA merujuk kepada kajian Gu et al. (2009)

\begin{tabular}{ccc}
\hline Pencetus & Jenis Pencetus & Jujukan \\
\hline Beta-globin & Ke hadapan & 5'-GCCTTGAGCATCTGG-3' \\
& Berbalik & 5'-AAGCCTCTACTTGAATCCT-3' \\
16S rDNA & Ke hadapan & 5'-AACGCGAAGAACCTTAC-3' \\
Gu et al. (2009) & Berbalik & 5'-CGGTGTGTACAAGACCC-3' \\
\hline
\end{tabular}

JADUAL 3. Kitar suhu semasa proses amplifikasi RT-PCR

\begin{tabular}{lccc}
\hline Proses amplifikasi & Suhu $\left({ }^{\circ} \mathrm{C}\right)$ & Masa & Kitaran \\
\hline Pra-penyahaslian & 95 & $2 \mathrm{~min}$ & 1 \\
Penyahaslian & 95 & $1 \mathrm{~min}$ & \\
Penyepuhan & 51 & $20 \mathrm{~s}$ \\
Pemanjangan & 72 & $20 \mathrm{~s}$ & 35 \\
Pemanjangan akhir & 72 & $5 \mathrm{~min}$ & 1 \\
\hline
\end{tabular}

JADUAL 4. Bacaan spektrofotometri bagi purata kandungan DNA genom dalam sampel segar (tanpa penyimpanan; 0 bulan), sampel 1 bulan, sampel 2 bulan, sampel 3 bulan dan sampel 4 bulan

\begin{tabular}{cccc}
\hline Bulan & $\begin{array}{c}\text { Purata kepekatan DNA } \\
(\mathrm{ng} / \mu \mathrm{L})\end{array}$ & Purata nilai $\mathrm{A}_{260 / 280}$ & ${\text { Purata nilai } \mathrm{A}_{260 / 230}}$ \\
\hline 0 & 133.0 & 1.81 & 2.07 \\
1 & 158.9 & 1.97 & 1.11 \\
2 & 228.0 & 1.84 & 1.01 \\
3 & 269.7 & 2.45 & 2.66 \\
4 & 239.2 & 1.98 & 1.60 \\
\hline
\end{tabular}

Julat bacaan DNA yang tulen pada penyerapan optik bagi $\mathrm{A}_{260 / 280}$ adalah 1.8-2.0 (Pham et al. 2015; Steven et al. 2007); Julat bacaan DNA yang tulen pada penyerapan optik bagi $\mathrm{A}_{260 / 230}$ adalah 1.8-2.2 (Pham et al. 2015; Steven et al. 2007). $\mathrm{A}_{260}$ penyerapan optik asid nukleik; $\mathrm{A}_{280}$ penyerapan optik protein; $\mathrm{A}_{230}$ penyerapan optik polisakarida $(n=5)$ 
diamplifikasikan. Kelima-lima lajur adalah sampel segar manusia yang terdiri daripada 5 orang subjek yang sihat ( $n=5$; kriteria seperti dalam Jadual 1). Rajah 1(b), 1(c), 1(d) dan 1(e) pula menunjukkan fragmen bersaiz $\sim 280$ pb gagal diamplifikasi sebaliknya fragmen bersaiz $~ 130, \sim 230$ dan $\sim 400 \mathrm{pb}$ pula berjaya diamplifikasikan. Ini menunjukkan hanya sampel segar (Rajah 1(a)) sahaja yang berupaya menghasilkan fragmen beta-globin manusia ( 280 pb). Sampel selepas penyimpanan selama 1, 2, 3, dan 4 bulan tidak berjaya mengamplifikasi fragmen beta-globin.

Bagi 16S rDNA bakteria pula menunjukkan gen bakteria $\sim 40$ pb berjaya diamplifikasi bagi sampel 2, 3 dan 4 bulan penyimpanan (Rajah 2; L4-L6). Kawalan negatif (DNA templat telah digantikan dengan air suling yang steril), sampel segar dan 1 bulan menunjukkan tiada jalur yang terhasil. Jalur gen bakteria bersaiz $\sim 440 \mathrm{pb}$ kemudiannya dijujuk terus bagi mengetahui jenis bakteria yang hadir.

\section{ANALISIS JUJUKAN AMPLIFIKASI RT-PCR DNA GENOM DARIPADA AIR LIUR}

Pengenalpastian gen berdasarkan saiz jalur yang dikesan oleh pencetus telah dilakukan dengan menggunakan perisian Primer BLAST di laman web http://www.ncbi. nlm.nih.gov. Hasil amplifikasi fragmen DNA bersaiz $\sim 280 \mathrm{pb}$ telah ditentukan merupakan gen beta-globin manusia melalui analisis in silico terhadap jujukan di pangkalan data NCBI. Analisis kesemua fragmen DNA yang diamplifikasikan selain daripada gen beta-globin manusia yang bersaiz $\sim 130 \mathrm{pb}, \sim 230 \mathrm{pb}$ dan $\sim 400 \mathrm{pb}$ telah berjaya dikenal pasti. Fragmen yang bersaiz 130 dan $\sim 400 \mathrm{pb}$ merupakan jujukan yang terdapat dalam genom 'Archaea'. Fragmen yang bersaiz 230 pb pada Rajah 1(e) pula merupakan jujukan nukleotida yang terletak pada kromosom 2 manusia (homo sapien).

Analisis penjujukan 16S rDNA bakteria bagi sampel 2 dan 3 bulan menggunakan analisis perisian yang sama (BLASTN pada pangkalan data NCBI) menghasilkan jujukan di bawah nombor rujukan yang sama, iaitu NC_006814.3. Hal ini kerana sampel 2 bulan dan 3 bulan mempunyai jujukan DNA bagi spesies bakteria oral yang sama, iaitu Lactobacillus acidophilus dengan masing-masing mempunyai peratus persamaan sebanyak $88 \%$ dan $89 \%$ (Jadual 5). Manakala bagi sampel 4 bulan pula menunjukkan sebanyak $85 \%$ persamaan jujukan dengan spesies bakteria oral Pseudomonas denitrificans. Hasil penjujukan bagi sampel 2 dan 3 bulan masing-masing mempunyai nilai $\mathrm{E}$ (Evalue) pada 3e-46 dan 3e-47, manakala sampel 4 bulan memberikan nilai E yang lebih tinggi iaitu 2e-06. Nilai E yang lebih rendah menunjukkan wujudnya persamaan antara jujukan 16S rDNA dengan jujukan yang terdapat pada pangkalan data (subject) (Jadual 5).

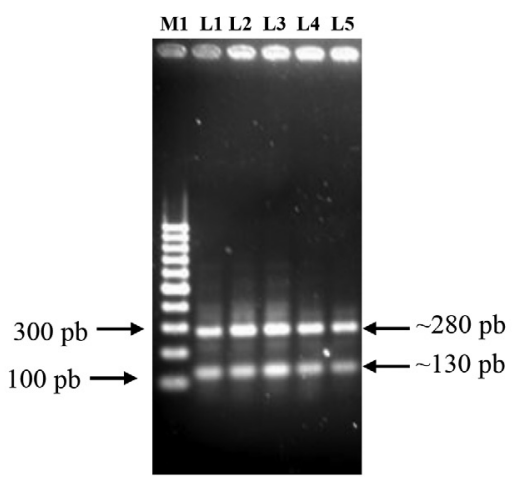

(a)

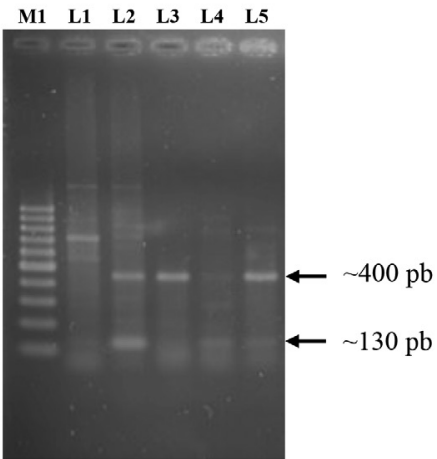

(b)

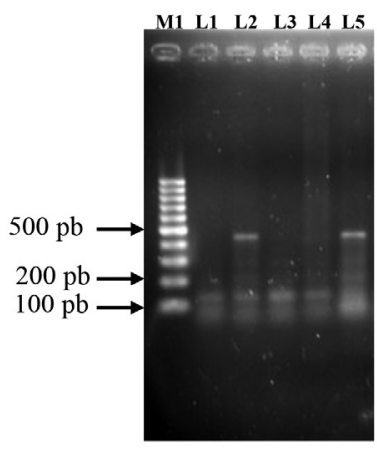

(c)

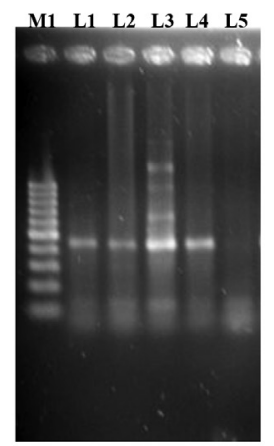

(d)

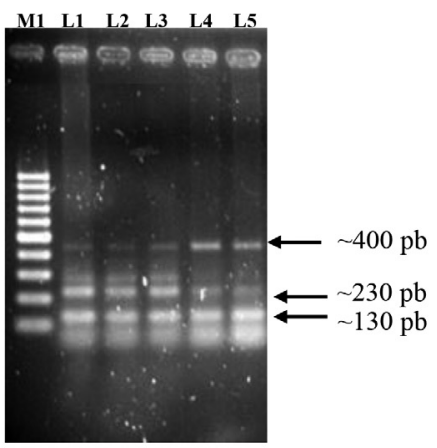

(e)

RAJAH 1. Profil elektroforesis hasil pengamplifikasian sampel DNA genom pada $2 \%$ (b/i) gel agarosa pada $80 \mathrm{~V}$ selama 90 minit bagi (a) sampel segar, (b) sampel 1 bulan, (c) sampel 2 bulan, (d) sampel 3 bulan dan (e) sampel 4 bulan.

(Lajur M1 : penanda $\lambda$ Hind III, Lajur L1-L5: hasil produk PCR individu 1 hingga 5) ( $n=5$ ) 


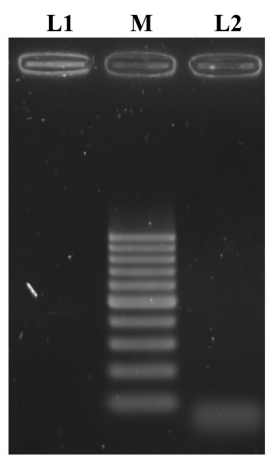

(a)

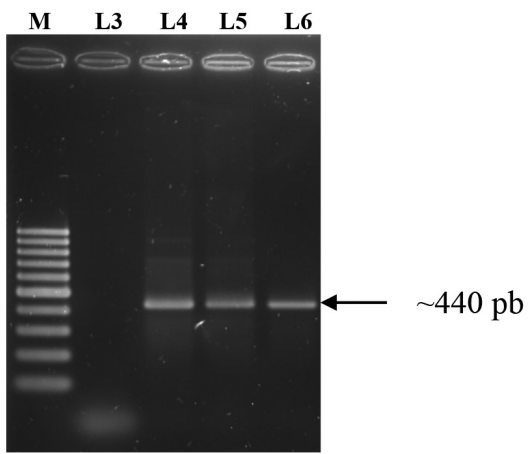

(b)

RAJAH 2. Profil elektroforesis $1.7 \%$ (b/i) gel agarosa bagi produk RT-PCR menunjukkan (a) L1: kawalan negatif (DNA templat telah digantikan dengan air suling yang steril), M: Penanda 100 pb, dan L2: sampel segar; (b) M: Penanda 100 pb, L3: sampel 1 bulan, L4: sampel 2 bulan, L5: sampel 3 bulan, L6: sampel 4 bulan. Sampel air liur 2, 3 dan 4 bulan telah menghasilkan jalur amplifikasi jujukan $16 \mathrm{~S}$ rDNA bakteria $(n=5)$

JADUAL 5. Hasil jujukan DNA bagi sampel segar, 1, 2, 3 dan 4 bulan

\begin{tabular}{cccccc}
\hline Sampel & Spesies Bakteria Oral & Query & Nilai E & Peratus Persamaan & Nombor Induk \\
\hline Segar & \multicolumn{4}{r}{ Penjujukan tidak berjaya mengenal pasti bakteria 16S rDNA } \\
1 bulan & \multicolumn{4}{r}{ Penjujukan tidak berjaya mengenal pasti bakteria 16S rDNA } \\
2 bulan & Lactobacillus acidophilus & $77 \%$ & $3 \mathrm{e}-46$ & $88 \%$ & NC_006814.3 \\
3 bulan & Lactobacillus acidophilus & $74 \%$ & $3 \mathrm{e}-47$ & $89 \%$ & NC_006814.3 \\
4 bulan & Pseudomonas denitricans & $27 \%$ & $2 \mathrm{e}-06$ & $85 \%$ & NC_020829.1 \\
\hline
\end{tabular}

\section{PERBINCANGAN}

Pemencilan DNA daripada sampel air liur manusia telah dijalankan menggunakan kaedah fenol-kloroform. Kaedah fenol-kloroform adalah kaedah yang lebih baik berbanding kaedah $\mathrm{NaOH}$ bagi memencilkan DNA (Cheng et al. 2010). Kajian Cheng et al. (2010) mendapati tiada perbezaan statistik yang signifikan antara kaedah fenol-kloroform dan kit QIAamp. Manakala kaedah $\mathrm{NaOH}$ menghasilkan ketulenan DNA yang kurang tulen dengan bacaan $\mathrm{A}_{260 / 280}$ 2.4, iaitu melebihi lingkungan bacaan ketulenan DNA (Cheng et al. 2010)581 bp, and 300 bp. DNA yang tulen mempunyai purata nisbah bacaan $\mathrm{A}_{260 / 280}$ dalam lingkungan 1.8-2.0 dan purata nisbah bacaan $\mathrm{A}_{260 / 230}$ dalam lingkungan 1.8-2.2 (Rusterholz et al. 2015). Bacaan $\mathrm{A}_{260 / 280}$ bagi sampel 3 bulan menunjukkan sampel mempunyai kontaminasi protein. Manakala, bacaan $\mathrm{A}_{260 / 230}$ menunjukkan sampel 1, 2, 3 dan 4 bulan mempunyai pelumusan polisakarida.

Air liur disimpan di dalam penimbal TNE pada suhu bilik pada tempoh tertentu sebelum DNA dipencilkan. Penimbal TNE bertindak menstabilkan DNA di dalam sampel air liur. Namun, DNA dalam kajian ini tidak mencapai tahap kualiti yang dikehendaki (mengikut bacaan spektrofotometri; Jadual 4), iaitu dalam lingkungan 1.82.0 dan 1.8-2.2 masing-masing bagi nisbah bacaan $\mathrm{A}_{260 / 280}$ dan $\mathrm{A}_{260 / 230}$ (Rusterholz et al. 2015). Hal ini mungkin disebabkan oleh pengurangan terhadap integriti DNA genom hasil daripada aktiviti DNase yang mendegradasi sampel DNA (Maron \& Johnson 2015). Penurunan kandungan DNA yang dipencilkan pada sampel air liur yang disimpan pada suhu bilik berkemungkinan berlakunya degradasi DNA hasil aktiviti DNase yang terdapat di dalam sampel kajian. Selain itu, kekerapan melakukan proses nyahbekuan sampel DNA air liur juga boleh menyumbang kepada pengurangan integriti dan kualiti DNA (Cuhadar et al. 2013; Romanazzi et al. 2015).

Analisis PCR dilakukan untuk mengamplifikasi kawasan jujukan gen beta-globin manusia. Hanya sampel segar yang berjaya mengamplifikasi fragmen bersaiz 280 pb (gen beta-globin; Rajah 1(a)). Ini menunjukkan kualiti DNA genom daripada pengekstrakan sampel segar lebih baik berbanding hasil pengekstrakan DNA genom daripada sampel 1, 2, 3 dan 4 bulan. Dalam kajian ini didapati fragmen bersaiz $\sim 130$ dan $\sim 400$ pb telah diamplifikasikan pada sampel 1, 2, 3 dan 4 bulan. Fragmen seterusnya dikenal pasti merupakan gen daripada genom Archaea melalui perbandingan jujukan DNA dengan pangkalan data The National Center for Biotechnology Information (NCBI) (Rajah 1(b)-1(e)).

Seterusnya, amplifikasi fragmen menggunakan pencetus berbalik yang universal terhadap jujukan $16 \mathrm{~S}$ rDNA bakteria dijalankan bagi mengetahui kualiti DNA. Hasil analisis jujukan bagi sampel segar dan 1 bulan menunjukkan tiada jujukan $16 \mathrm{~S}$ rDNA bakteria pada sampel. Manakala, bagi sampel 2 dan 3 bulan mempunyai persamaan jujukan dengan bakteria Lactobacillus acidophilus masing-masing sebanyak $88 \%$ dan $89 \%$. 
Sampel 4 bulan pula mempunyai persamaan jujukan bakteria Pseudomonas denitrificans sebanyak $85 \%$ persamaan (Jadual 5). Tempoh penyimpanan yang lama mengurangkan lagi kualiti DNA pada sampel air liur.

Dalam kajian ini, templat DNA air liur sebanyak $10 \mathrm{ng}$ telah digunakan. Kajian yang dilakukan oleh Rus Dina et al. (2014) terhadap sampel purba berusia lebih 2000 tahun dan mempunyai DNA yang berkualiti rendah serta kurang tulen masih berupaya mengamplifikasi DNA sasaran pada kandungan templat DNA serendah $10 \mathrm{ng}$. Pemadanan yang dilakukan di antara jujukan yang dianalisis dengan jujukan yang terdapat pada pangkalan data adalah bertujuan untuk mengetahui peratusan persamaan dengan jujukan di dalam pangkalan data NCBI serta jenis bakteria yang wujud dalam sampel tersebut. Bacaan nilai E dapat menunjukkan jujukan yang dikaji mempunyai jujukan yang hampir sama dengan jujukan spesis bakteria Lactobacillus acidophilus dan Pseudomonas denitrificans yang terdapat pada pangkalan data NCBI.

\section{KESIMPULAN}

Hanya sampel segar yang diambil dalam tempoh 2-4 jam sahaja yang berjaya mengamplifikasi kawasan beta-globin daripada DNA genom manusia. Jujukan 16S rDNA bakteria oral pula didapati pada sampel air liur 2, 3 dan 4 bulan. Sampel 2 dan 3 bulan dikontaminasi oleh Lactobacillus acidophilus, manakala sampel 4 bulan pula dikontaminasi oleh Pseudomonas denitrifican. Sampel air liur yang disimpan dalam penimbal TNE pada suhu bilik tidak mampu menstabilkan DNA genom air liur manusia untuk jangka masa lama dan hanya berkesan untuk tempoh yang singkat iaitu kurang daripada 1 bulan. Oleh itu, sampel segar masih diperlukan bagi memencil DNA daripada air liur.

\section{PENGHARGAAN}

Penyelidikan ini dijalankan di bawah geran ERGS/1/2012/ SKK11/UKM/02/5 tajaan Kementerian Pengajian Tinggi Malaysia dan DPP-2015-033 tajaan Universiti Kebangsaan Malaysia. Jutaan terima kasih diucapkan kepada kumpulan Teknologi Perkembangan Sel Stem Mamalia yang terlibat iaitu Dr. Zulham Yamamoto dan Wan Hayatunnisa Wan Hisham Balkiah di atas bantuan yang dihulurkan sepanjang menjalankan penyelidikan ini.

\section{RUJUKAN}

Cheng, T.H., Chen, S.P., Lu, T.C., Chen, W.C., Sher, J.S. \& Shieh, Y.S. 2010. Optimal DNA extraction from buccal swab samples. Journal of Medical Sciences 30(4): 149-154.

Chiappin, S., Antonelli, G., Gatti, R. \& De Palo, E.F. 2007. Air liur specimen: A new laboratory tool for diagnostic and basic investigation. Clinica Chimica Acta 383(1): 30-40.

Cuhadar, S., Koseoglu, M., Atay, A. \& Dirican, A. 2013. The effect of storage time and freeze-thaw cycles on the stability of serum samples. Biochemia Medica 23(1): 70-77.

Gu, F., Li, Y., Zhou, C., Wong, D.T.W., Ho, C.M., Qi, F. \& Shi, W. 2009. Bacterial 16S rRNA/rDNA profiling in the liquid phase of human saliva. The Open Dentistry Journal 3: 80-84.
Hebels, D.G.A.J., Georgiadis, P., Keun, H.C., Athersuch, T.J., Vineis, P., Vermeulen, R., Portengen, L. \& Ingvar, A. 2013. Performance in omics analyses of blood samples in longterm storage: Opportunities for the exploitation of existing biobanks in environmental health research. Environmental Health Perspectives 121(4): 480-487.

Javaid, M.A., Ahmed, A.S., Durand, R. \& Tran, S.D. 2015. Air liur as a diagnostic tool for oral and systemic diseases. Journal of Oral Biology and Craniofacial Research 6: 67-76.

Lima, D.P., Diniz, D.G., Moimaz, S.A., Sumida, D.H. \& Okamoto, A.C. 2010. Air liur: Reflection of the body. International Journal of Infectious Diseases 14(3): 184-188.

Luke, R., Khan, S.N., Iqbal, P.S., Soman, R.R., Chakkarayan, J. \& Krishnan, V. 2015. Estimation of specific salivary enzymatic biomarkers in individuals with gingivitis and chronic periodontitis: A clinical and biochemical study. Journal of International Oral Health 7(9): 54-57.

Madalli, V.B., Basavaraddi, S.M., Burde, K. \& Horatti, P. 2013. Air liur-a diagnostic tool. IOSR Journal of Dental and Medical Sciences 11(6): 96-99.

Malathi, N., Mythili, S. \& Vasanthi, H.R. 2014. Air liurry diagnostics: A brief review. ISRN dentistry 2014: 1-8.

Maron, J.L. \& Johnson, K.L. 2015. Comparative performance analyses of commercially available products for salivary collection and nucleic acid processing in the newborn. Biotechnic \& Histochemistry 90(8): 581-586.

Mohd Faiz, E., Shahrul Hisham, Z.A., Saiful Anuar, K., Maryati, A.R., Sahidan, S. \& Rohaya, M.A.W. 2012. Proteomic analysis of saliva identifies potential biomarkers for orthodontic tooth movement. The Scientific World Journal 2012: Article ID. 647240.

Pham, T.V., Huynh, L.T.T. \& Nguyen, T.H. 2015. Modified DNA extraction method for the detection of Aspergillus flavus and Aspergillus parasiticus in dried food. Proceedings of the 5th International Conference on Biomedical Engineering in Vietnam 46: 339-342.

Rathnayake, N., Åkerman, S., Klinge, B., Lundegren, N., Jansson, H., Tryselius, Y., Sorsa, T. \& Gustafsson, A. 2013. Air liurry biomarkers for detection of systemic diseases. PLOS ONE 8(4): $1-5$.

Romanazzi, V., Traversi, D., Lorenzi, E. \& Gilli, G. 2015. Effects of freezing storage on the DNA extraction and microbial evaluation from anaerobic digested sludges. BMC Research Notes 8: 1-8.

Rus Dina, R.D., Shahrul Hisham, Z.A., Sahidan, S., Rohaya, M.A.W.\& Intan Zarina, Z.A. 2014. Molecular mitochondrial DNA and radiographic approaches for human archaeology identification. Sains Malaysiana 43(10): 1523-1535.

Rusterholz, H.P., Ursenbacher, S., Coray, A., Weibel, U. \& Baur, B. 2015. DNA quantity and quality in remnants of traffic-killed specimens of an endangered longhorn beetle: A comparison of different methods. Journal of Insect Science 15(1): 1-5.

Shahrul Hisham, Z.A., Mohd Faiz, E., Rohaya, M.A.W., Yosni, B. \& Sahidan, S. 2010. Profil aktiviti laktat dehidrogenase, asid fosfatase rintang tartarat dan alkalin fosfatase pada air liur semasa rawatan ortodontik. Sains Malaysiana 39(3): 405-412.

Smith, S. \& Morin, P.A. 2005. Optimal storage conditions for highly dilute DNA samples: A role for trehalose as a preserving agent. Journal Forensic Science 50(5): 1101-1108.

Spielmann, N. \& Wong, D.T. 2011. Air liur: Diagnostics and therapeutic perspectives. Oral Diseases 17(4): 345-354. 
Steven, A.W., Barton, E.S. \& John, R.M. 2007. Laboratory Investigations in Molecular Biology. Sudbury: Jones and Bartlett Publishers.

Streckfus, C., Bigler, L., Dellinger, T., Dai, X., Kingman, A. \& Thigpen, J.T. 2000. The presence of soluble c-erbB-2 in saliva and serum among women with breast carcinoma: A preliminary study. Clinical Cancer Research 6(6): 2363 2370.

Tina, P., Justin, C.W., Peter, B., Karam, K. \& Chamindie, P. 2011. Diagnostic potential of saliva: Current state and future application. Clinical Chemistry 57(5): 675-687.

Wong, D.T. 2006. Air liurry diagnostics powered by nanotechnologies, proteomics and genomics. The Journal of the American Dental Association 137(3): 313-321.

Zulham, Y., Ikmal, M.J., Rohaya, M.A.W., Intan Zarina, Z.A., Sahidan, S. \& Shahrul Hisham, Z.A. 2013. Orthodontic treatment effects on inflammatory marker profiles in saliva before and after 2 archwire changes. AIP Conference Proceedings 1571: 208-214.

Rohaya Megat Abdul Wahab

Jabatan Ortodontik, Fakulti Pergigian

Universiti Kebangsaan Malaysia

50300 Kuala Lumpur, Wilayah Persekutuan

Malaysia

Farah Amirah Mohd Nasri \& Shahrul Hisham Zainal Ariffin* Pusat Pengajian Biosains dan Bioteknologi

Fakulti Sains dan Teknologi

Universiti Kebangsaan Malaysia

43600 UKM Bangi, Selangor Darul Ehsan

Malaysia
Intan Zarina Zainol Abidin

Pusat Sumber Penyelidikan

Cyberjaya University College of Medical Sciences

63000 Cyberjaya, Selangor Darul Ehsan

Malaysia.

Zaidah Zainal Ariffin

Jabatan Biologi, Fakulti Sains Gunaan

Universiti Teknologi MARA

40450 Shah Alam, Selangor Darul Ehsan

Malaysia

Zaidah Zainal Ariffin

Atta-ur Rahman, Institut Kajian Ubat Semulajadi, Fakulti Farmasi

Universiti Teknologi MARA

42300 Bandar Puncak Alam, Selangor Darul Ehsan

Malaysia

Muhammad Dain Yazid

Pusat Kejuruteraan Tisu, Tingkat 12, Blok Klinikal

Pusat Perubatan Universiti Kebangsaan Malaysia

Jalan Yaacob Latiff

56000 Cheras, Kuala Lumpur, Wilayah Persekutuan

Malaysia

*Pengarang untuk surat-menyurat; email: shahroy8@ gmail.com

Diserahkan: 3 Julai 2016

Diterima: 20 Disember 2017 